\title{
Governing Sustainable Development for Highland Areas: A Case Study of Subang Jaya, Malaysia
}

\author{
Ismail Muhammad ${ }^{1}$, Khairul Nizam Othman ${ }^{2 *}$ Nurulhuda Ali ${ }^{3}$
}

\begin{abstract}
Rapid urban growth and development sprawling towards highland areas required a comprehensive and prudent development management. The development management system for highland areas need for continuous and prudent monitoring tools and mechanism even though there are existences of various regulations and guidelines and complete development process system for highland development, issues pertinently to continuous geo- disaster that occurred since 1919.Concern arose on unsustainable development, safety measures, development process and control mechanism, professionalism and doubtful decision making. Thus, embedding a balance and sustainable development to accommodate sustainable future living in term of human habitation is crucial to ensure a sustainable highland development, factors such as safety, environmental preservation, development infrastructure and maintenance need to be addressed accordingly. This paper focuses on revealing the needs of sustainable development for highland areas in accordance to the development stakeholders, legislations and crucial inputs for the development. A case study of high rise development in Subang Jaya, Malaysia shows that there are crucial needs for geotechnical inputs, government interventions, stakeholder's needs and precise highland development guidelines and processes. Furthermore, in determine sustainable development, there are crucial needs for geotechnical inputs, public inputs and prudent planning control documents. Governing sustainable development highland areas needs a comprehensive development process, management and control mechanism.
\end{abstract}

Keywords: Highland Areas, Development Legislations, Property Development Process, Sustainable Development

\section{Introduction}

Development growth in Malaysia is increasing rapidly in pursuing towards developed country in 2020. The urban areas were filled with property development and most of urban areas are highly dense. Currently development has encroached toward highland area as most urban areas have being developed and land become scare. Developing highland areas need an extensive consideration as compared to low lying areas. Highland area is defined as Environmental Sensitive area (ESA,2005) and located above 150 meter from sea level with contour above 150-300 meter (ESA Rank 3) Economic Planning Unit (2002). This area is permissible for development with controlled development where the type and intensity of the development shall be strictly controlled depending on the nature of the constraints. Malaysia has a suffiecient development provisions, acts and guidelines to control development on highland areas. Development plan is a crucial planning control instrument which defined the allowable plot ratio, density, slope stabilisation requirement, mitigation, presevation of natural waterways, vegetation etc. However, there are other needs and consideration that need to be adhered in developing highland areas in macro and micro context for a holistic development control.

Currently continuous Geo disaster incidents in high land areas have developed concern on safety and development sustainability. Public has stated the issues and concern on land use planning, law and regulation, safety management, maintenance, funding, accountability and professionalism pertaining to development sustainability on high land area. Basically public has lost their confident regarding to the development and decision making process. Although there are existence of various regulations and guidelines for highland and steep slope development, issues such as geodisasters, unsustainable development, public concern, effected development and economic growth remain unsolved. There are needs to formulate best approaches and practices through collaborations of local authorities and the stakeholders in the related project site on highland in ensuring sustainable development on highland areas. The important variable and consideration that need to be adhered need to be formulated. Thus, addressing those issues and needs are crucial to achieve a balance development towards establishing sustainable development on highland areas with added value to safety, environmental protection and sustainability.

\section{High Land Development Issues in Malaysia}

The rapid growth of development in Malaysia has resulted development encroaches to highland areas. It is also due to the demand of property buyer for highland property for panoramic location (Othman \& Alias, 2011). Thus, need for new infrastructure and building construction has disturbed stable highland areas that have challenged the terrain and natural environment. However, the development was not prudently monitored. (Alias, et al., 2014) added that development encroachment has created massive development issues pertinently on geo disaster incidents such as debris fall, landslide, rock fall, and land erosion.

Actions have been taken with development control mechanism with the existence of various legislation, development policies, development plans and guidelines to mitigate environmental sustainability that defined the mitigation and presevation prosedures, allowable development in controlling density, plot ratio, slope stabilisation presevation of natural waterways and vegetation (Anuar and Khairul, 2012). Even then, extensive numbers of geo-diaster events still continues to present (Gue et al., 2002; 
Anuar and Khairul, 2012) (refer to Table 1). Samah, F. A. (n.d.) further added geo-disaster happened due to most made slopes (construction) and heavy rainfall. Alias et al., 2014, stated that the geo-disaster were identified since 1919, however major geo-disaster incident found in 1961 with fatality, property and monetary loss .Thus, it shows gap in protecting the environment and determining sustainable development for hill land areas. (Alias et al., 2014) added that the geo-disaster tragedies generally gave an impact to the depreciation of living environment values and property values.

Table 1 Major Geodisaster in Malaysia since 1961

\begin{tabular}{|c|c|c|c|}
\hline Geo Disaster Location & Date & Consequence & $\begin{array}{l}\text { Estimat } \\
\text { ed Loss } \\
\text { (RM } \\
\text { million) }\end{array}$ \\
\hline $\begin{array}{l}\text { Ringlet, Cameron } \\
\text { Highlands, Perak }\end{array}$ & 1961 & 16 deaths & 35 \\
\hline $\begin{array}{l}\text { Highland } \\
\text { Selangor }\end{array}$ & 1993 & 48 deaths & 185 \\
\hline $\begin{array}{l}\text { Genting Sempah route } \\
\text { to Genting highland, } \\
\text { Selangor }\end{array}$ & 1995 & 20 deaths & 48 \\
\hline $\begin{array}{l}\text { NKVE (Gua } \\
\text { Tempurung) Perak }\end{array}$ & 1996 & $\begin{array}{l}1 \text { death, } \\
\text { expressway } \\
\text { closed for } 14 \\
\text { days }\end{array}$ & 17 \\
\hline $\begin{array}{l}\text { Debris Flow Dipang } \\
\text { Post, Perak }\end{array}$ & 1996 & 44 deaths & 69 \\
\hline $\begin{array}{l}\text { Debris Flow Keningau, } \\
\text { Sabah }\end{array}$ & 1996 & 302 deaths & 459 \\
\hline Simunjan, Sarawak & 2002 & 16 deaths & 32 \\
\hline $\begin{array}{l}\text { KM 44, Simpang Pulai } \\
\text { route to Cameron } \\
\text { Highlands, Pahang }\end{array}$ & 2000 & $\begin{array}{l}\text { Road opened } \\
\text { in } 2004 \text { ( } 4 \text { yrs } \\
\text { delay) }\end{array}$ & 355 \\
\hline $\begin{array}{l}\text { NKVE (Bukit Lanjan), } \\
\text { Selangor }\end{array}$ & 2003 & $\begin{array}{l}\text { expressway } \\
\text { closed for } 6 \\
\text { months }\end{array}$ & 860 \\
\hline $\begin{array}{l}\text { Kg. Pasir, hulu Klang, } \\
\text { selangor }\end{array}$ & 2006 & 4 deaths & 21 \\
\hline $\begin{array}{l}\begin{array}{l}\text { Bukit Antarabangsa, } \\
\text { Selangor }\end{array} \\
\end{array}$ & 2008 & 5 deaths & 200 \\
\hline $\begin{array}{l}\text { Kampung Baru Cina, } \\
\text { Kapit, Sarawak }\end{array}$ & 2007 & 2 deaths & \\
\hline Hulu Langat, Selangor & 2011 & 16 deaths & \\
\hline $\begin{array}{l}\text { Puncak setiawangasa, } \\
\text { Kuala Lumpur }\end{array}$ & 2012 & - & \\
\hline Putra Height, Selangor & 2013 & - & \\
\hline $\begin{array}{l}\text { Kuala Lumpur Karak } \\
\text { expressway, Pahang }\end{array}$ & 2015 & - & \\
\hline $\begin{array}{l}\text { Cameron Highland, } \\
\text { Pahang }\end{array}$ & 2016 & 1 deaths & \\
\hline
\end{tabular}

The geological setting is among the most important aspect that need to take into account in examining any development. The awareness of geological and geographical setting that change upon climate changes and natural disaster is still lacking in the decision making. Previously the geological aspect seems to be neglected in planning development. It was only since 2008 emphasised on geology and climate change has been inserted in the development process (Othman et al., 2011). Besides of development control weaknessess, there are other weaknesses in governing highland development. (Hashim, 2008), explains that the ineffectiveness of environmental management caused by, mis-regulation, fragmented empowerment of legislations and inconsistent decision making (Alias et al., 2011). Ali et al., 2008, added that the complexity of implementing land policy and environmental measure for environmental protection were worsen as it is influenced by political, economic and social circumstances.

\section{Property Development Process for Highland Areas}

Development process in Malaysia was governed under the Ministry of Housing and Local Government (MHLG). In April 2007, a centralised mechanism namely the One Stop Centre (OSC) was in place to govern the development process. The OSC is an initiative to improve the government delivery system and act as an independent body to facilitate and monitor the development process at the local authorities (MHLG, 2008). Fig. 1 explains the flow, relevant agencies and documents of the development process. Currently, the OSC has being part of the local authority organisation in every state in Malaysia. Prior to the introduction of the OSC, submission for approval was done separately and in sequence (Abdullah et al., 2011). All planning approvals are subject to the planning permission process referred under Section IV, Town and Country Planning Act, 1976 (Act 172).

(Othman et al., 2014) explained for development that involves highland areas, the development process was extended to special committee held by the state government to pre-evaluate the development permission before final approval by the OSC committee. The special committee is a requirement to the highland development guidelines. However, currently only three (3) states are having these committee and guidelines that is the State of Selangor, Penang and The Federal Territory of Kuala Lumpur. The guidelines is a new development control mechanism to oversee highland development activities through proper planning and control for implementing agencies, developers, property owners, contractors, engineers and the public as a guide in planning, developing and maintaining highland and the surrounding areas. The guidelines mentioned are as follows:

- Garis Panduan Perancangan Pembangunan di Kawasan Bukit dan Cerun bagi Wilayah Persekutuan Kuala Lumpur 2010 (GPWPKL 2010)

- Garis Panduan Perancangan Pembangunan Di Kawasan Bukit Dan Tanah Tinggi Negeri Selangor, 2010

\section{- Penang Guideline for Hill site Development 2012}

These guidelines provide an administrative aspects, development control, and development process; and references in planning approval process. Development feasibility, settlement safety, geo hazard risk and management of environmental sensitive area are the main concern is of those guidelines. These guidelines provide mitigating measures for the development process by appointing advisory body (TCPD Selangor, 2010) and safety measures (TCPD Pulau Pinang, 2012). 


\section{Analysis of Findings and Discussion}

This paper is to determine the importance needs for sustainable development on high land areas in the development process. Data collection was made through case study of high rise development in Subang Jaya and content analysis on public engagement documents. The data was analyzed and evaluated to streamline important variable and considerations, technical instruments and reveals the needs and impact towards ensuring sustainable development for highland development.

\subsection{Case Study: Housing Development in Subang Jaya}

The proposed development by Alam Megah comprises of housing (apartment) and other facilities on 23.16 acre of land (refer Table 2). The site comprises of 800 units of dwelling and other facilities and located on high land in developed urban area (Fig. 1). The proposed site is located on the crest of a low hill which has been subjected to cutting and filling works. Man-made slopes are found surrounding the proposed site with a relatively flat area at the center part the site. Fig. 2 shows the slope terrain analysis of the proposed site. About $58.74 \%$ of the site is of flat to gently sloping ground with average slope gradients less or equal to $15^{\circ}$ (Class I) which has low geotechnical limitations and highly suitable for development. About $15 \%$ of the site is of moderate steep slopes with average gradients from $16^{\circ}-25^{\circ}$ (Class II) which has moderate geotechnical limitations and moderately suitable for development. Approximately $9.20 \%$ of the site is covered by slopes with average slope gradients from $26^{\circ}-35^{\circ}$ (Class III) that has high geotechnical limitations and low suitability for development. About $17.06 \%$ of the site is occupied by slopes steeper than $35^{\circ}$ (Class IV). The highest ground lies at the center part of the site with the elevation of about RL $106 \mathrm{~m}$ whereas the lowest ground lies at the Northern part of the site with elevation of about RL $56 \mathrm{~m}$. The elevation difference of the proposed site is about $50 \mathrm{~m}$.

Table 2. Development Components Details

\begin{tabular}{|c|c|c|c|}
\hline Development Component & Unit & Acre & $\%$ \\
\hline \multicolumn{4}{|l|}{ Housing } \\
\hline $\begin{array}{l}2 \text { Apartment Blocks } 27 \text { Storey (1322kp- } \\
1566 \mathrm{kp}) \text { including podium basement for car } \\
\text { park }\end{array}$ & 384 & 0.66 & 2.85 \\
\hline $\begin{array}{l}2 \text { Apartment Blocks } 19 \text { storey }(1082 \mathrm{kp}- \\
1503 \mathrm{kp}) \text { including podium base ment for car } \\
\text { park }\end{array}$ & 256 & 0.62 & 2.68 \\
\hline $\begin{array}{l}2 \text { Apartment Blocks } 261 / 2 \text { sorey (1868kp- } \\
1880 \mathrm{kp} \text { ) including } 41 / 2 \text { including Podium Car } \\
\text { park }\end{array}$ & 160 & 0.42 & 1.81 \\
\hline Sub total & 800 & 1.70 & 7.34 \\
\hline \multicolumn{4}{|l|}{ Others } \\
\hline $\begin{array}{l}\text { Single storey Podium car park and and } 2 \\
\text { Semi-Basemen car park }\end{array}$ & 1 & 2.63 & 11.36 \\
\hline Elevated Podium car park 4 1/2 storey & 1 & 0.64 & 2.76 \\
\hline Swimming pool & 2 & 0.76 & 3.28 \\
\hline Green area/playground /landscaping & - & 15.54 & 67.10 \\
\hline Electrical transmission & 1 & 0.06 & 0.26 \\
\hline Road / car park & - & 1.83 & 7.90 \\
\hline Sub total & 4 & 21.46 & 92.66 \\
\hline Total & - & 23.16 & 100.00 \\
\hline
\end{tabular}

Source: Alam Megah Development Proposal Report, 2015

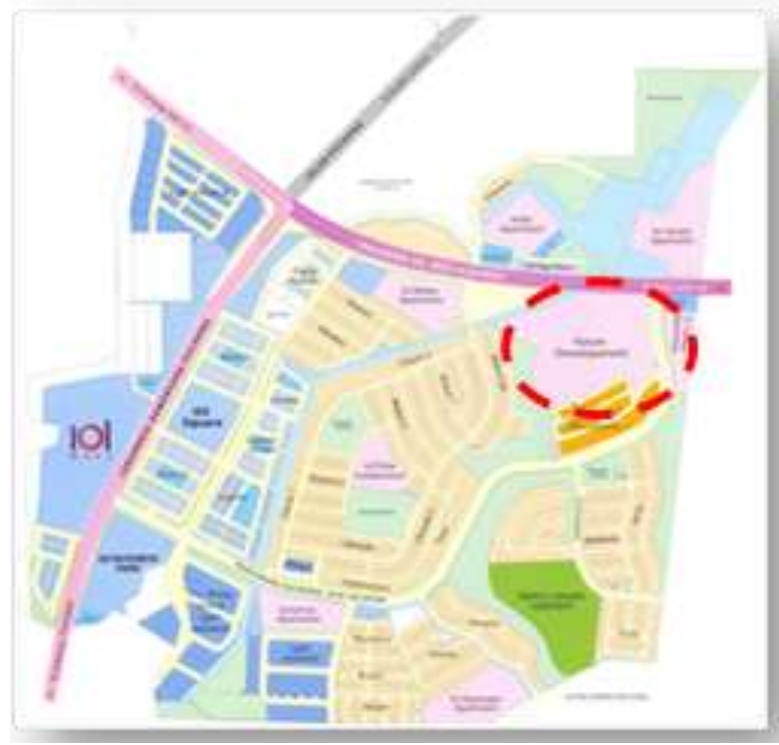

Figure 1: Project Site

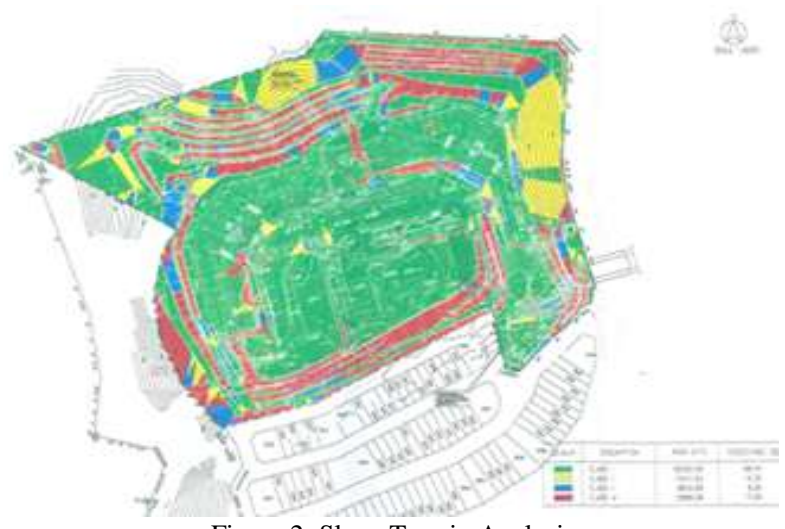

Figure 2: Slope Terrain Analysis

\subsection{Planning Control}

In the development process, there are numbers of crucial laws such as Town and Country Planning Act, 1976, (Act 172) Local Government Act, 1976 (act 171), Environment Quality Act, 1984, Uniform Building By Law, 1984, Street Drainage and Building Act 1974 etc (table 2.1). Beside those laws, there are guidelines such as planning guideline, environmental guidelines, buildings guideline etc. Furthermore, development plans (National Physical Plan, State Structure Plan and Local Plan) that integrate a top down development plan and strategies focusing on physical, environment, economic and social aspects based on the National Development Planning Framework comprises of three level such as national, state and local level towards vision 2020 (national development objective) (Bruton, 2007). These development plans were prepared under the Town and Country Planning Act, 1976 (ACT 172) provisions.

The most crucial initial reference for development is the development plan which provide strategies and approaches in development with legalisation provision. It defined the allowable plot ratio, density, slope stabilisation requirement, mitigation, presevation of natural waterways, vegetation etc. However, those guidelines have weaknesses that need to be overcomed such as on the implementation and the intensity of the provision in those guidelines. 
The consideration in permitting development and its density as indicated in the current guidelines were based on the following variables:

\section{i. Development Suitability classes \\ ii. Height / contour level \\ iii. Slope gradient \\ iv. Environmental Sensitive area (ESA) classes \\ v. Risk Classification.}

vi. Technical report such as such as Development Proposal report, Geo-Technical Report, Erosion and Sediment Control Report, Environmental Impact Assessment Report and Earthworks Plan.

\subsection{Geotechnical Inputs}

\subsubsection{Topography and Subsoil Condition}

The existing level for the proposed site ranges from Rl 56m to $\mathrm{Rl} 106 \mathrm{~m}$. The natural groundwater level is generally low for the proposed development. Subsoil mainly consists of Sandy clay and Clayey sand. The following effective shear strength parameters for the overburden soil interpreted from consolidated isotropically iundrained triaxial compression tests and direct shear box tests $(60 \mathrm{mmx} 60 \mathrm{~mm}$ \& $300 \mathrm{~mm} \times 300 \mathrm{~mm})$ are adopted for slope stability analyses:-

- Overburden Soils with 'N'<50: $\Phi=32^{\circ}, \mathrm{c}^{\prime}=3 \mathrm{kPa}$

- Overburden Soils with 'N'>50: $\Phi=32^{\circ}, \mathrm{c}^{\prime}=15 \mathrm{kPa}$

\subsubsection{Geotechnical Design of Slope}

For new engineering slopes, the required FOS is in 1.4 in accordance to the "geotechnical Manual for Slopes" of the Hong Kong Geotechnical Engineering Office's (GEO). The slopes design is accordance to guidelines of slopes engineering.

Branch, Works Department (JKR), and the minimum FOS for Slope shall be not less than 1.5. Thus, slopes in the proposed site shall be designed to meet the FOS requirement by both GEO and Works Department. It is recommended gradient for cut slope is gentler than $1 \mathrm{~V}: 1.5 \mathrm{H}$ with $1.5 \mathrm{~m}$ width berm and the height for each berm not exceeding $6 \mathrm{~m}$. Gradient for fill slope should gentler than $1 \mathrm{~V}: 2 \mathrm{H}$ with $1.5 \mathrm{~m}$ width berm and the height for each berm not exceeding $6 \mathrm{~m}$.

In the stability analyses, all possible localized and global slip surfaces were checked using Spencer Methods for circular failure. Whereby, proposed platform with slopes are designed to achieve required FOS by re-profiling to gentler slope gradient or bye strengthening the slopes using soil nails.

Presently, all the strengthening works proposed for the site can achieve the required FOS of 1.5. It is recommended to carry out instrumentation monitoring works over the construction period up to end of defects liability period to gauge the performance of the engineered slopes and monitor the groundwater fluctuation. Instrumentation monitoring scheme consists of the following instruments (subject to change in later stage to suit the site conditions) could be adopted:-

a. Inclinometers - Horizontal ground movement monitoring. b. Building Settlement Markers/Settlement Markers vertical movement monitoring.

c. Observation Wells/Standpipes - Groundwater fluctuation monitoring

4.3.3 Geotechnical recommendations

a. Monitoring the engineered slopes and ground water fluctuation through instrumenting monitoring works including horizontal ground movement monitoring, vertical movement monitoring for building settlement markers/settlement markers and ground water fluctuation monitoring (observations on wells/stand pipes).

b. Improving the stability of slopes through slope strengthening design that adhere to the FOS requirement minimum at 1.4 and adopting measurable slope stabilisation and strengthening techniques.

c. Slope maintenance inspections need to be carried out including routine maintenances inspections and engineering inspections for maintenance.

\subsection{Public Engagement Inputs}

In the development process, public engagement was exercised in the pre-development stage namely at the local plan preparation process in accordance to section 14(1) Act 172. However, in the development application process, the public engagement exercise is not compulsory. The SJMC has initiated public engagement program to ensure the public and interested parties in collaboration with the state authority (State of Selangor), consultant, developer and political members to gain feedback from the public (stakeholders) to pursue the balance and sustainable development and to inform the involved stakeholders and public in projects within their area especially sensitive area such as highland area. For this project, 2 public briefings and 6 public hearing meetings has been undertaken before the planning approval. The outcomes of the meetings are as follows:

1. Concern on land slide risk for steep slopes areas

2. Concern on traffic conjestions due to additional traffic from the project and aslo due to single access of the project.

3. Safety concern due to highland development the may effect the developed surrounding areas incuding current residents and dwellings.

4. Concern on mitigation approach towards slope stability.

5. Landslide caused by water lock issue.

6. Upstream development affacting downstream existing development.

7. Concern on sufficiency of buffer zone and building set back.

There are two (2) major effects and implications from the public engagement initiated as follows:

1. Review on the project planning approval.

2. Review of planning guidelines and legislative requirements for high land areas.

\subsection{Summary of Findings}

The crucial facts revealed from the analysis were there are needs to streamline important variable and considerations, technical instruments and public needs in ensuring sustainable development on highland areas. Thus, precise variables and tools are crucial to be streamlined in the development continuous monitoring to maintain its 
sustainability should be adhered. In ensuring sustainable development on highland areas, prudent legislations and guidelines, public engagement inputs, planning control documents and geotechnical inputs are crucial. These viable and tools could ensure and mitigate the sustainability concern such as:

\subsubsection{Safety}

Safety concern was mitigating through enforcing FOS at 1.5. To ensure sustainability of the development, site evaluation should determine the site readiness in term of construction foundation, slope safety and efficient infrastructures in consideration on design, criteria and cost. Approaches to ensure the achievement of safe and sustainable high land development areas are as follows:

- Developments have to be monitor at every stage of development which is pre, during and post.

- Improve safety design for slope, infrastructure and buildings.

- Allocate sufficient fund for slope stabilisation that source from government authority and private owners.

- Geotechnical inputs

\subsubsection{Legislation and guideline}

Generally, current legislation and guideline is efficient. However, it should allocate more provision for public engagement in the planning approval stage, construction stage and monitoring stage. It is to ensure the social sustainability in ensuring sustainable development for highland areas in macro and micro context to ensure sound living habitat which is safe, peaceful and balance ambiance.

\subsubsection{Geotechnical Inputs}

Geotechnical inputs were being crucial tools in highland development process. It determines the site readiness and mitigation action in ensuring safety and sustainability of the site. The geotechnical variables on FOS requirement, monitoring and maintaining slope measures, stabilisation and strengthening engineering slope and structure is very important to be adhere in developing highland areas.

\subsubsection{Public Engagement Inputs}

Involving public in the development process is crucial especially in determining the localisation needs and concerns. The public engagement program should be legalised throughout the whole process of development. This is to ensure the local public habitation could be improve and preserve in the present of new development.

\subsubsection{Planning Control Documents}

Planning control documents such as development plan, guidelines, act and regulation is crucial to adhere in the development process. It has outlined considerations in permitting highland development (para 4.2) focusing on stability and safety of the development. However, the planning should be stringent on sensitive areas such as highland area, forest, water catchment areas etc.

\section{Conclusions}

The needs of sustainable development for highland areas should be in accordance to the development stakeholders, legislations, crucial variable, considerations and inputs for the development. A case study of high rise development in Subang Jaya, Malaysia shows that there are crucial needs for geo-technical inputs, government interventions, stakeholder's needs and precise highland development guidelines and processes. Furthermore, in determine sustainable development, there are crucial needs for geotechnical inputs, public inputs and prudent planning control documents. Highland development requires continuous monitoring, maintaining and managing mechanism in the implementation processes. The development guidelines and legislation should indicate the needs of public engagement specifically and balance with the developer's preferences without compromising the importance and requirements of geotechnical and planning control documents. These will be the primary tools on governing sustainable development for highland areas to ensure a comprehensive development process and management mechanism to spearhead towards sustainable development.

\section{Acknowledgment}

This work was supported by the Ministry of Urban Wellbeing, Housing \& Local Government, Malaysia and Subang Jaya Municipal Council, Malaysia.

\section{References}

1) Abdullah, A.A., Harun, Z., Rahman, A.H. (2011). Planning Processof Development Project in Malaysia Context : A Crucial Vrief Overview.International Journal of Applied Science and Technology vol 1. No 2. : April 2011

2) Adnan, A. H., \& Hasan, M. N. (2006). Towards Sustainable Development? The Evolution of Environmental Policy in Malaysia. United Kingdom: Blackwell Publishing Ltd.

3) Ali, N. H, Alias, A., Othman, K.N (2010). EIA in Malaysia : Issues and Challenges. Kuala Lumpur.

4) Alias, A., Ali, A.S., Othman, K.N. (2014). Land Development on High Land Areas: Comparison of Process Implementation and Legislation Effectiveness between Malaysia and Hong Kong. World Journal of Engineering and Technology, 2014, 2, 55-60, ISI Publication

5) Alias, A., Othman, K.N. (2012). Prospect and Sustainability of Property Development on Highland and Steep Slope Areas in Selangor-Malaysia: Re-Examining of Regulations and Guidelines . Proceeding $7^{\text {th }}$ Annual Legal research Symposium (COBRA 2012) RICS International Research Conference Las Vegas, USA

6) Alias, A., Othman, K.N., .Mohamad, Z., Ali, A.S. (2014). Land Development On Highland And Steep Slope Areas: Process Mechanism And Legislation Issues - A Study Of Malaysia And Hong Kong Proceedings of $7^{\text {th }}$ International Real Estate Research Symposium 2104 (IRERS): Unlocking the Potential of Real estate, Putrajaya

7) Ang, S. L., \& Wilkinson, S. J. (2008). Is the social agenda driving sustainable property development in Melbourne Australia? Emeraldinsight, 331-343.

8) Bruton, M. J. (2007). Malaysia The Planning of a Nation. Malaysia: PERSADA (Persatuan Pegawai Perancang Bandar dan Desa MALAYSIA).

9) Chan, N.W. (1998), Responding to landslide hazards in rapidly developing Malaysia: a case of economics versus environmental 
protection, Journal of Disaster Prevention and Management, Vol.7 (No.1), pp. 14-27

10) Department of Town and Country Planning, State of Penang (2012), Penang Guideline for Hill site Development, Penang

11) Department of Town and Country Planning, State of Selangor (2010). Garis Panduan Perancangan Pembangunan Di Kawasan Bukit Dan Tanah Tinggi Negeri Selangor, Selangor

12) Education, C. o. (2007). Sustainable Development : An Introduction. Centre of Environment Education.

13) Frey, H., \& Yaneske, P. (2007). Vision of sustainability cities and regions. London and New York: Taylor \& Francis.

14) Gue, I., Sew, S., Tan, I., \& Chin, Y. (2002). Mitigating the Risk of Landslide on Hill-Site Development in Malaysia, (July), 2225

15) Hasan, M. N., \& Adnan, A. H. (2003). Sustainable Development Indicators Initiatives in Malaysia - Novel Approaches and Viable Framework. Selangor: Institute for Environment and Development (LESTARI) Universiti Kebangsaan Malaysia.

16) Hashim, H. S. (2008). Challenges in Planning for Sustainability. World Habitat day 2008 \& World Town Planning Day 2008 Seminar. Putrajaya: Institute for Environment and development (LESTARI), Universiti Kebangsaan Malaysia.

17) Kuala Lumpur City Council, (2010),Garis Panduan Perancangan Pembangunan di Kawasan Bukit dan Cerun bagi Wilayah Persekutuan Kuala Lumpur, Kuala Lumpur

18) Malaysia, F. D. (2006). National Urbanisation Policy. Kuala Lumpur: Government of Malaysia.

19) Malaysia, F. T. (2008). Town and country Planning 50 years. Kuala Lumpur: Federal Town and Country Planning Peninsular Malaysia.

20) Malaysia, T. F. (2004). Sustaining Sustainability. Malaysia Town Plan, 60-70.

21) Mannis, A. (2002). Indicators of Sustainable Development. Austria: Environmental Software and services.

22) Ministry of Housing and Local Government, Malaysia (MHLG) (2008). Upgrading of the Procedure on the Delivery System and Development Plan Process and the Implementation of the One Stop Centre (2nd edition). Pusat Bandar Damansara, Kuala Lumpur, Malaysia.

23) Othman, K.N., Alias, A. \& Ali, N.H. (2011). Property Development Prospect on Highland and Steep Slope Areas- A case Study in Bukit Antarabangsa, Proceedings of Asian Conference of Real Estate 2011 (ACRE 2011), Johor, Malaysia

24) Othman, K.N., Alias, A., Ali, N.H \& Muhammad I (2014). ReExamining the Control Mechanism for Sustainable Property Development on Highland Areas: A Case of Malaysia. $2^{\text {nd }}$ International Conference on Sustainable Development (ICSD 2014), Rome, Italy. Published : European Journal of Sustainable Development (2014), 3, 4, 219-230

25) Redcliff, M. (1987). Sustainable development exploring the contradictions. London: Routledge.

26) Robert, W. k., Thomas, M. P., \& Anthony, A. L. (2005). What Is Sustainable Development. Environment: Science and Policy for Sustainable Development, Volume 47 , p 8-21.

27) Samah, F. A. (n.d.). PAPER 10: Landslides In The Hillside Development In The Hulu Klang ,, 148-162.

28) Smith, N. (1984). Uneven development. Oxford: Blackwell.

29) UN. (1993). Earth Summit Agenda 21: The UN Programme of Action from Rio. New York: United Nation.

30) UPEN \& JPBD, ( 2007), Selangor Development Planning Direction 2025, Selangor Economic Planning Unit (UPEN) \& Department of Town and Country Planning, Selangor, Malaysia. 